\title{
Implementasi Kebijakan Pajak Reklame di Badan Pendapatan Daerah (BAPENDA) Kabupaten Subang
}

\author{
Komir Bastaman \\ Fakultas Ilmu Administrasi Universitas Subang \\ komirbastaman60@gmail.com
}

\begin{abstract}
Abstrak
Implementasi Kebijakan Pajak Reklame di BAPENDA (Badan Pendapatan Daerah) Kabupaten Subang merupakan kebijakan pemerintah Subang yang pada dasarnya adalah untuk peningkatan Pendapatan Asli Daerah (PAD) Kabupaten Subang. Tujuan penelitian ini dalah untuk mengetahui Mengapa Implementasi Kebijakan Pajak Reklame di Badan Pendapatan Daerah (BAPENDA) Kabupaten Subang Belum Optimal. Penelitian dan penulisan ini membahas hal-hal yang berkaitan dengan Implementasi Kebijakan Pajak Reklame di Badan Pendapatan Daerah (BAPENDA) Kabupaten Subang dengan menggunakan teori dari Van Metter and Van Horn yaitu Standae dan Sasaran Kebijakan, Sumber Daya, Hubungan Antar Organisasi, Karakteristik Agen Pelaksana, Kondisi social politik dan ekonomi, serta Disposisi Implementor. Pendekatan yang digunakan pada penelitian ini adalah menggunakan pendekatan kualitatif. Pendekatan ini bersifat deskriptip, karena penelitian ini bertujuan untuk mengungkapkan permasalahan dalam kehidupan kerja organisasi pemerintah melalui observasi, wawancara, studi kepustakaan dan dokumentasi. Sumber data diperoleh dari informan melalui pengamatan dan wawancara secara langsung dan dokumen diperoleh dalam bentuk peraturan-peraturan dan pengolahan data. Berdasarkan hasil penelitian menunjukan bahwa Implementasi Kebijakan Pajak Reklame di Badan Pendapatan Darah (BAPENDA) Kabupaten Subang belum optimal sehingga tujuan dari kebijakan tersebut bekum tercapai.
\end{abstract}

Kata Kunci : Implementasi, Kebijakan

\section{Abstract}

Policy Implementation of Tax Policy in BAPENDA (Regional Revenue Agency) of Subang Regency is a Subang government policy which basically is to increase Subang Regency's Original Local Revenue (PAD). The purpose of this research is to find out why the implementation of advertisement tax policy in Subang Regional Revenue Agency (BAPENDA) has not been optimal. This research and writing discusses matters relating to the Implementation of Advertisement Tax Policy in Subang Regency's Regional Revenue 
Agency (BAPENDA) using theories from Van Metter and Van Horn namely Standae and Policy Targets, Resources, Inter-Organizational Relations, Implementing Agency Characteristics, Socio-political and economic conditions, and Implementation Disposition. The approach used in this research is to use a qualitative approach. This approach is descriptive, because this study aims to reveal problems in the work life of government organizations through observation, interviews, literature studies and documentation. Sources of data obtained from informants through direct observation and interviews and documents obtained in the form of regulations and data processing. Based on the results of the study showed that the Implementation of Advertisement Tax Policy in the Subang Regency's Blood Revenue Agency (BAPENDA) was not optimal so that the objectives of the policy were not yet achieved.

Keywords: Policy, Implementation

\section{Pendahuluan}

Kebijakan publik merupakan serangkaian tindakan yang ditetapkan oleh pemerintah yang mempunyai tujuan tertentu berkenaan dengan masalah tertentu yang diorientasikan pada penyelesaian masalah publik. Kebijakan publik yang ditetapkan pemerintah diharapkan mampu mengatasi kebutuhan atau memenuhi harapan terhadap suatu kondisi yang mempunyai dampak bagi banyak orang. Selama ini pemerintah membuat dan mengesahkan kebijakan, namun pemerintah pada umumnya belum berani menjamin apakah kebijakan yang telah dibuat dan disahkan tersebut mampu dilaksanakan dengan baik dan berhasil sehingga dapat memberikan perubahan yang sesuai dengan harapan masyarakat. Pada hakikatnya, tujuan dari dibuatnya suatu kebijakan adalah untuk dilaksanakan. Siklus kebijakan publik terdiri dari tiga kegiatan pokok, yaitu perumusan kebijakan, implementasi kebijakan serta pengawasan dan evaluasi pelaksanaan kebijakan. Implementasi kebijakan merupakan tahap dimana suatu kebijakan dilaksanakan secara maksimal dan dapat mencapai tujuan kebijakan itu sendiri. Tahapan implementasi menjadi begitu penting karena kebijakan bagi pembangunan suatu bangsa tidak berarti apaapa jika tidak dapat dilaksanakan dengan baik dan benar. Tanpa implementasi suatu kebijakan hanya daftar keinginan saja.

Pajak Daerah, yang selanjutnya disebut pajak, adalah kontribusi wajib kepada daerah yang terhutang oleh orang pribadi atau badan yang bersifat memaksa berdasarkan Undang-undang, dengan tidak mendapatkan imbalan secara langsung dan digunakan untuk keperluan daerah bagi sebesar-besarnya kemakmuran rakyat salah satunya melalui pembangunan Daerah. Kewenangan pemerintah daerah, baik provinsi maupun kota untuk memungut biaya dari masyarakat diatur dalam UU No. 28 Tahun 2009 tentang Pajak Daerah dan Retribusi Daerah. Namun saat ini, daerah memiliki kewenangan sendiri atas pelaksanaan rumah tangganya atau disebut dengan desentralisasi. Desentralisai adalah penyerahan urusan-urusan pemerintah pusat kepada pemerintah daerah yang pada dasarnya menjadi wewenang dan tanggung jawab daerah sepenuhnya atau kebijakan, perencanaan, pelaksanaan dan segi-segi pembiayaan yang diatur dalam Perda Subang No.10 Tahun 2010 tentang Pajak Daerah Kabupaten Subang. 
Pendapatan Asli Daerah (PAD), Dana Perimbangan dan Bagi Hasil Pajak Provinsi merupakan jenis penerimaan untuk membiayai pembangunan dan pemerintah daerah di kabupaten Subang. Salah satu jenis pendapatan pajak daerah yang penting peranannya dalam pembiayaan pembangunan daerah pemerintah kota Subang adalah melalui penerimaan Pajak Reklame. Pajak reklame yang selanjutnya disebut pajak adalah pungutan daerah atas penyelenggaraan reklame. Pajak reklame merupakan salah satu dari pajak daerah dan retribusi daerah yang merupakan bagian dari sumber pendapatan asli Daerah (PAD). Pemungutan pajak tidak terlepas dari kebijakan atau peraturan yang dibuat oleh pemrintah itu sendiri dan konsekuensi kebijakan bagi masyarakat yang tidak taat. Menurut Mardiasmo (2010:2) bahwa agar pemungutan pajak tidak menimbulkan hambatan atau perlawanan, maka pemungutan pajak harus memenuhi syarat sebagai berikut : (1) Pemungutan pajak harus adil (Syarat Keadilan); (2) Pemungutan pajak harus berdasarkan Undang-undang (Syarat Yuridis); (3) Tidak mengganggu perekonomian (Syarat Ekonomis); (4) Pemungutan pajak harus efisien (Syarat Finansil); (5) Sistem pemungutuan pajak harus sederhana.

Berdasarkan hasil penelitian yang dilakukan di Badan Pendapatan Daerah Kabupaten Subang terdapat permasalahan yaitu implementasi kebijakan pajak reklame belum terlaksana dengan baik. Sementara itu jika melihat isi dari PERDA No. 10 Tahun 2010 sudah cukup baik dan jelas. Objek pajak reklame atau wajib pajak yang menjadi sasaran Bapenda dalam pajak reklame yang menerbitkan reklame belum memperlihatkan respon positif terhadap aturan-aturan atau kebijakan tersebut. Namun saat ini di Kecamatan Subang masih banyak pajak reklame yang belum masuk. Terhitung sampai dengan desember 2018 hanya ada 244 wajib pajak reklame yang sudah terdaftar atau mendaftarkan diri di Kec. subang. Jika dilihat pada kenyataan yang ada bahwa di kecamatan subang memiliki potensi reklame yang melebihi jumlah tersebut. Sebut saja di sekitara JL. Ukong Sutaatmaja atau yang lebih dikenal dengan sebutan Gang Panglejar. Di sana terdapat banyak sekali reklame yang menjadi potensi bagi pendapatan daerah dari mulai masuk ke jalan tersebut hingga ujung jalan tersebut. Kawasan tersebut merupakan Kawasan perotokoan dimana setiap toko memiliki reklame yang memasuki zona reklame yang telah ditentukan oleh Bapenda. Kawasasn atau zona reklame adalah batas-batas wilayah tertentu yang sesuai dengan pemanfaatan wilayah tersebut yang dapat digunakan untuk pemasangan reklame. Dari sekian banyak toko yang memajang reklame, Kawasan tersebut menjadi Kawasan paling tidak sadar terhadap pendaftaran reklame dan pembayaran pajak reklame. Banyak reklame yang belum terdaftar di Kawasan tersebut. Hal ini disebabkan oleh wajib pajak yang tidak melek pada peraturan dan tidak patuh pada aturan yang telah ditetapkan. Kurangnya sosialisasi dari pihak implementor pun menjadi salah satu penyebab kurangnya kesadaran wajib pajak. harus digiatkan kembali sosialisai akan pentingnya mendaftarkan reklame dan mengurus pajaknya. Terjadi penurunan realisasi pendapatan pajak daerah pada bidang pajak reklmae. Pada tahun 2017 Bapenda mampu memungut pajak sebesar 188.632.737.144 atau bila dipersentasikan sekitar 114,92\%, menurun pada tahun 2018 menjadi 177.862.441.946 atau bila dipersentasikan sekitar 102,14\%. Meskipun pada ke dua tahun tersebut memiliki realisasi diatas 100\%, namun penurunan tersebut tidak dapat dihiraukan begitu saja. Tentu itu menjadi permasalahan yang berarti bagi pendapatan daerah di Kabupaten 
Subang. Hal ini berkenaan dengan kurang sadarnya wajib pajak yang menjadi sasaran pajak reklame di Kec. Subang dan kurangnya sosialisai dari Bapenda mengenai pajak reklame. Jika melihat dari Nilai Fungsi Jalan sebesar 2,8 untuk Subang, seharusnya penurunan ini tidak terjadi karena Subang memiliki NFJ kedua tertinggi setelah NFJ pada jalan tol yaitu sebesar 3,0. Nilai Fungsi Jalan berperan dalam penentuan jumlah pajak reklame yang harus dibayar oleh wajib pajak reklame. Data tersebut merupakan rekapitulasi pendapatan pajak reklame yang ada di Kab. Subang. Bapenda tidak memiliki rekapitulasi pendapatan pajak per kecamatan karena reklame bersifat global. Artinya tidak dapat diukur pendapatannya dalam jumlah sedikit. Berbeda dengan pajak lainnya seperti Pajak Bumi dan Bangunan (PBB) atau Pajak Kendaraan Bermotor yang dapat dihitung per ruang lingkup atau perkecamatan misalnya. Bapenda hanya memiliki jumlah reklame perkecamatan saja tidak untuk pendapatan pajaknya. Akan tetapi tidak ada salahnya jika Bapenda mencoba melakukan pendataan pendapatan perkecamatan.

Dalam Perda No. 10 Tahun 2010 diatur juga didalamnya tentang lama masa tayang reklame dan pelaksanaan perpanjangan masa tayang reklame. Masa tayang reklame beragam, mulai dari perminggu, perbulan, hingga per tahun. Bagi reklame yang sudah habis masa tayangnya akan diberikan surat peringatan kepada objek atau wajib pajak. Apabila objek pajak tidak melakukan perpanjangan masa tayang reklame, maka akan dilakukan penertiban terhadap reklame tersebut. Penertiban reklame yang sudah habis masa tayangnya ditugaskan kepada satpol PP seperti yang disebutkan dalam Perda No. 10 Tahun 2010. Namun beberapa tahun ke belakang satpol PP menjadi kurang tanggap atau seakan lamban dalam merespon apabila surat tugas telah diterbitkan dari BAPENDA Subang. Alhasil reklame pun menjadi berceceran dan tidak teratur sehingga mengurangi kesan estetik untuk Kota Subang. Hal ini menandakan kurangnya koordinasi antara BAPENDA dan Satpol PP. Dikatakan bahwa biaya penertiban yang kurang mengingat penertiban reklame dilakukan setiap hari dan tentunya membutuhkan anggaran yang berbeda-beda dalam sekali penertibannya. dengan banyaknya jumlah reklame yang harus ditertibkan Satpol PP sering meminta biaya akomodasi lebih kepada BAPENDA Subang dalam penertiban reklame. Sedangkan BAPENDA memiliki anggaran terbatas dan bukan hanya untuk penertiban reklame saja. Kemudian melihat hal tersebut, tim pelaksana pajak reklame memutuskan untuk melakukan penertiban sendiri. Biasanya pun tim pelaksana selalu terjun ke lapangan secara langsung untuk cek lokasi apabila ada pengajuan penerbitan reklame baru. Namun karena tugas tim pelaksana bertambah yaitu melakukan penertiban, tim pelaksana kekurangan personil atau sumber daya manusia. Saat ini petugas bagian pajak reklame hanya terdiri dari 3 orang yaki bagian administrasi (kepala seksi) 1 orang dan 2 orang lainnya bagian lapangan untuk pengecekan lokasi serta penertiban. Melihat keadaan tersebut tak jarang kepala seksi pun ikut terjun ke lapangan. Mengingat lokasi pajak reklame tersebar maka kurangnya petugas lapangan pendataan wajib pajak sebagian besar berdomisili di luar kabupaten Subang dibutuhkan penambahan personil atau sumber daya manusia. Sedangkan menurut penuturan dari kepala seksi pajak reklame setidaknya dibutuhkan penambahan 4 orang di bagian pajak reklame dengan tujuan agar tugas yang dilaksanakan tidak terlalu berat. Terlebih mengingat bahwa petugas yang mengelola reklame sekarang sering melakukan sendiri penertiban pada reklame yang sudah habis masa 
tayangnya. Hal ini ternyata menjadi permasalahan bagi pemerintah Kabupaten Subang dalam mengoptimalkan pendapatannya dari pajak reklame menjadi setidaknya berkurang. Selain itu, reklame yang tidak cepat ditertibkan pun menjadi sampah di Kabupaten Subang pada akhirnya dan mengurangi keindahan lingkungan. Apabila suatu kebijakan tidak tepat atau tidak bisa mengurangi masalah yang merupakan sasaran kebijakan, maka kebijakan itu mungkin mengalami kegagalan sekalipun sudah di implementasikan dengan baik. Begitupun sebaliknya. Pada kebijakan yang berhasil akan mengalami kegagalan pula pada akhirnya apabila kurang baik dalam implementasinya. Berdasarkan masalah yang berkaitan dengan implementasi kebijakan pajak reklame di atas, maka peneliti merumuskan indikator masalah sebagai berikut: Kurangnya sosiali dari pihak implementor yakni BAPENDA mengenai pentingnya membayar pajak reklame bagi wajib pajak reklame; Terjadi penurunan realisai pendapatan pajak rekalem di Kab. Subang dari 114,92\% menjadi 102,14\%; Kurangnya koordinasi, komunikasi dan kerjasama antara BAPENDA dengan Satpol PP dalam penertiban reklame di Kabupaten Subang. Reklame yang masa izin tayang/pasangnya sudah habis sebaiknya disegerakan ditertibkan, agar tidak mengganggu lingkungan dan berakhir menjadi sampah dan Kurangnya sumber daya pelaksana atau tim pelaksana pajak reklame di BAPENDA Kabupaten Subang. Butuh tambahan petugas dalam hal mengelola reklame mengingat reklame tidak sering menjadi tugas yang kasar dalam penertibannya. Setidaknya dibutuhkan 4 orang tambahan pada bagian pajak reklame.

\section{Kerangka Teori}

\section{Konsep Kebijakan Publik}

Mengenai pengertian kebijakan publik, banyak para ahli-ahli kebijakan yang memberikan pendapatnya masing-masing mengenai definisi kebijakan publik yang semua benar dan saling melengkapi. Menurut Dunn (2013:132) menyebutkan istilah Kebijakan Publik (Public Policy) sebagai: "Pola ketergantungan yang kompleks dari pilihan-pilihan kolektif yang saling tergantung, termasuk keputusan-keputusan untuk tidak bertindak, yang dibuat oleh badan atau kantor pemeritah". Kebijakan publik sesuai apa yang dikemukakan oleh Dunn mengisyaratkan adanya pilihan-pilihan kolektif yang saling bergantung satu dengan yang lainnya, dimana didalamnya keputusankeputusan untuk melakukan tindakan. Kebijakan publik yang dimaksud dibuat oleh badan atau kantor pemerintah. Suatu kebijakan apabila telah dibuat, maka harus diimplementasikan untuk dilaksanakan oleh unit-unit administrasi yang memobilisasikan sumber daya finansial dan manusia, serta dievaluasikan agar dapat dijadikan sebagai mekanisme pengawasan terhadap kebijakan tersebut sesuai dengan tujuan kebijakan itu sendiri. Berdasarkan definisi dan pendapat para ahli di atas, maka dapat dikemukakan bahwa kebijakan publik merupakan tindakan-tindakan tertentu yang dilakukan oleh pemerintah ataupun pejabat pemerintah. Setiap kebijakan yang dibuat pemerintah pasti memiliki suatu tujuan, sehingga kebijakan publik berguna untuk memecahkan masalah atau problem yang ada dalam kehidupan 
masyarakat. Kebijakan publik sangat perlu adanya karena tugas pemerintah sebagai pelayan masyarakat yang harus merumuskan tindakan-tindakan untuk masyarakat. Menurut Dunn (2003:44) mendefinisikan analisis kebijakan, "sebagai intelektual praktis untuk menciptakan, secara kritis menilai, dan mengkomunikasikan pengetahuan tentang dan didalam proses kebijakan". Dari definisi di atas tersebut bahwa analisis kebijakan bertujuan untuk memberikan informasi, kritik, serta arahan-arahan kepada para pembuat serta pelaksana kebijakan untuk menjalankan kebijakan dengan tepat, sehingga tujuan utama kebijakan yakni untuk mengatasi permasalahan di dalam prosesnya tersebut dapat dilaksanakan dengan baik.

\section{Tahap-tahap Kebijakan}

Proses pembuatan kebijakan merupakan proses yang kompleks karena melibatkan banyak proses maupun variabel yang harus dikaji. Untuk itu, agar lebih mudah dalam mengkaji kebijakan publik maka diperlukan beberapa tahap. Adapun tahapan-tahapan tersebut menurut Dunn (dalam Winarno, 2007:35-37) sebagai berikut:

1) Tahap Penyusunan Agenda

Para pejabat yang dipilih dan diangkat menempatkan masalah pada agenda publik. Sebelumnya masalah-masalah ini berkompetisi terlebih dahulu untuk dapat masuk ke dalam agenda kebijakan. Pada akhirnya, beberapa masalah masuk ke agenda kebijakan para perumus kebijakan. Pada tahap ini suatu masalah mungkin tidak disentuh sama sekali, sementara masalah yang lain ditetapkan menjadi fokus pembahasan, atau ada pula masalah karena alasanalasan tertentu ditunda untuk waktu yang lama.

2) Tahap Formulasi Kebijakan

Masalah telah masuk ke agenda kebijakan kemudian dibahas oleh para pembuat kebijakan. Masalah-masalah tadi didefinisikan untuk kemudian dicari pemecahan masalah terbaik. Pemecahan masalah tersebut berasal dari berbagai alternatif atau pilihan kebijakan (policy alternatives/policy options) yang ada. Sama halnya dengan perjuangan suatu masalah untuk masuk kedalam agenda kebijakan, dalam tahap perumusan kebijakan masing-masing alternatif bersaing untuk dapat dipilih sebagai kebijakan yang diambil untuk memecahkan masalah. Pada tahap ini, masing-masing aktor akan "bermain" untuk mengusulkan pemecahan masalah terbaik.

3) Tahap Adopsi Kebijakan

Dari sekian banyak alternatif kebijakan yang ditawarkan oleh para perumus kebijakan, pada akhirnya salah satu alternatif kebijakan tersebut diadopsi dengan dukungan dari mayoritas legislatif, konsensus antara direktur lembaga atau keputusan peradilan.

4) Tahap Implementasi Kebijakan

Suatu program kebijakan hanya akan menjadi catatan-catatan elit, jika program tersebut tidak diimplementasikan. Oleh karena itu, keputusan program kebijakan yang telah diambil sebagai alternatif pemecahan masalah harus diimplementasikan, yakni dilaksanakan 
oleh badan-badan administrasi maupun agen-agen pemerintah ditingkat bawah. Kebijakan yang telah diambil dilaksanakan oleh unit-unit administrasi yang memobilisasikan sumber daya finansial dan manusia. Pada tahap implementasi ini berbagai kepentingan akan saling bersaing. Beberapa tahap implementasi kebijakan mendapat dukungan para pelaksana, namun beberapa yang lain mungkin akan ditentang oleh para pelaksana.

5) Tahap Evaluasi Kebijakan

Pada tahap ini kebijakan yang telah dijalankan akan dinilai atau dievaluasi, untuk melihat sejauh mana kebijakan yang dibuat telah mampu memecahkan masalah. Kebijakan publik pada dasarnya dibuat untuk meraih dampak yang diinginkan. Dalam hal ini, memecahkan masalah yang dihadapi masyarakat. Oleh karena itu, ditentukanlah ukuran-ukuran atau kriteria-kriteria yang menjadi dasar untuk menilai apakah kebijakan publik telah meraih dampak yang diinginkan. Tahap-tahap kebijakan yang sesuai dengan yang di kemukakan oleh Dunn mengisyaratkan bahwa kebijakan itu bukanlah proses sederhana, diperlukan tahap demi tahap dalam proses pembuatan kebijakan mulai dari menghasilkan, melaksanakan serta mengevaluasi kebijakan itu sendiri.

\section{Implementasi Kebijakan}

Implementasi kebijakan merupakan aspek yang sangat penting di dalam seluruh proses kebijakan karena kebijakan publik yang telah dibuat akan bermanfaat bila diimplementasikan. Suatu kebijakan harus diimplementasikan agar mempunyai dampak dari tujuan yang diinginkan, karena jika kebijakan tanpa implementasi hanyalah daftar keinginan.

Implementasi kebijaksanaan menurut kamus Webster dalam Wahab (2004:64), merumuskan secara pendek bahwa implementasi kebijakan yakni "to implement" ("Mengimplementasikan") berarti "to provide the means of carrying out" ("Menyediakan sarana untuk melaksanakan sesuatu"), "to give practical effect to" ("Menimbulkan dampak atau akibat terhadap sesuatu").

Pengertian tersebut mempunyai arti bahwa dalam mengimplementasikan sesuatu harus menyediakan sarana yang mendukung agar dalam pelaksanaan sesuatu tersebut menimbulkan dampak atau akibat.

Mazmania dan Sabatier dalam Rusli (2013:87), mendefinisikan implementasi kebijakan sebagai: "Pelaksanaan keputusan kebijakan dasar, biasanya dalam bentuk undang-undang, namun dapat pula dalam bentuk perintah-perintah atau keputusan-keputusan eksekutif yang penting atau keputusan badan peradilan. Lazimnya, keputusan tersebut mendefinisikan masalah yang ingin di atasi, menyebutkan secara tegas tujuan atau saran yang ingin dicapai, dan berbagai cara untuk menstrukturkan atau mengatur proses implementasinya". Dalam perspektif ini, bagi para pelaksananya, implementasi kegiatan harus dipahami dan kemudian dinilai dari hasil yang diraih setelah sebuah kebijakan itu dilaksanakan. Pemahaman tersebut tidak berhenti setelah pelaksana melakukan kegiatan untuk mencapai tujuan, tetapi terus berlanjut hingga dicapainya sebuah tujuan yang ditetapkan. Proses implementasi kebijakan baru 
dapat dimulai setelah undang-undang kebijakan publik telah ditetapkan, program-program telah dibuat, dan dana telah di alokasikan untuk pencapaian tujuan kebijakan tersebut. Perubahan taraf kesejahteraan masyarakat dianggap sebagai hasil akhir kebijakan yang disebut juga sebagai "policy income" atau "policy impact". Dengan sendirinya didalam hasil akhir kebijakan, kebijakan termasuk juga hasil sampingan disamping "policy performance" yang diperoleh. Menurut Teori Implementasi Kebijakan Van Meter Van Horn dalam Rusli (2015 : 91) bahwa implementasi kebijakan adalah "tindakan-tindakan yang dilakukan baik oleh individu-individu atau pejabat-pejabat atau kelompok-kelompok pemerintah atau swasta yang diarahkan pada tercapainya tujuan-tujuan yang telah di gariskan dalam keputusan kebijakan." Berdasarkan definisi di atas bahwa implementasi kebijakan merupakan tindakan-tindakan yang dilakukan oleh pemerintah untuk mencapai tujuan yang telah ditetapkan dalam suatu keputusan kebijakan. Akan tetapi pemerintah dalam membuat kebijakan juga harus mengkaji terlebih dahulu apakah kebijakan tersebut dapat memberikan dampak yang buruk atau tidak bagi masyarakat. Hal tersebut bertujuan agar suatu kebijakan tidak bertentangan dengan masyarakat apalagi sampai merugikan masyarakat. Seberapa baiknya suatu kebijakan kalau tidak dipersiapkan dan direncanakan dengan baik implementasinya, maka apa yang menjadi tujuan kebijakan publik tidak akan terwujud. Begitu pula sebaliknya, sebaik apapun persiapan dan perencanaan implementasi kebijakan apabila tidak diimplementasikan dengan baik oleh para pelaksana kebijakan, maka apa yang menjadi tujuan kebijakan maka tidak bisa tercapai.

Keberhasilan implementasi kebijakan dipengeruhi oleh banyak faktor. Jadi implementasi kebijakan tidak hanya terbatas pada tindakan atau prilaku unit birokrasi untuk bertanggung jawab untuk melaksanakan program, tetapi lebih dari itu jaringan sosial politik dan ekonomi yang berpengaruh pada semua pihak yang terlibat dan akhirnya terdapat sesuatu dampak yang tidak diharapkan. Menurut Grindle dalam Rusli (2013:95) ada sejumlah persamaan mendasar dari berbagai model implementasi yang ditawarkan oleh sejumlah ahli dalam membedah persoalan implementasi kebijakan dalam mencapai tujuannya. Secara umum, dalam proses impelementasi sebuah kebijakan, para ahli mengidentifikasi berbagai faktor yang mempengaruhi keberhasilan implementasi sebuah kebijakan. Dari kumpulan faktor tersebut setidaknya ada tiga faktor utama yang sering disebut, meskipun dengan titik tekan yang berbeda-beda. Ketiga faktor tersebut adalah: (1) Isi atau content kebijakan. Kebijakan yang baik dari sisi content setidaknya mempunyai sifat-sifat sebagai berikut: jelas, tidak distorsif, didukung oleh dasar teori yang teruji, mudah dikomunikasikan ke kelompok target, didukung oleh sumber daya baik manusia maupun finansial yang baik; (2) Implementor atau pelaksana kebijakan dan kelompok target. Pelaksanaan implementasi kebijakan tergantung pada badan pelaksana kebijakan (implementor) dan kelompok target (target groups). Implementor harus mempunyai kapabilitas, kompetensi, komitmen dan konsistensi untuk melaksanakan sebuah kebijakan sesuai dengan arahan dari penentu kebijakan (policy makers). Selain itu, kelompok target yang terdidik dan relatif homogen akan lebih mudah menerima sebuah kebijakan daripada kelompok yang tertutup, tradisional dan heterogen. Lebih 
lanjut, kelompok target yang merupakan bagian besar dari populasi juga akan lebih mempersulit keberhasilan implementasi kebijakan; (3) Lingkungan. Keadaan sosial-ekonomi, politik, dukungan publik maupun kultur populasi tempat sebuah kebijakan diimplementasikan juga akan mempengaruhi keberhasilan kebijakan publik. Kondisi sosial-ekonomi sebuah masyarakat yang maju, sistem politik yang stabil dan demokratis, dukungan baik dari konstituen maupun elit penguasa, dan budaya keseharian masyarakat yang mendukung akan mempermudah implementasi sebuah kebijakan.

Ketiga hal tersebut yang menjadi benang merah diantara para ahli terkait sejumlah faktor yang mempengaruhi proses implementasi kebijakan dalam mencapai tujuannya. Barangkali yang berbeda diantara sejumlah ahli adalah mengenai bagaimana model itu dirumuskan menjadi sesuatu yang mudah diterima oleh penggunanya, termasuk oleh orang yang paling awam sekalipun. Bukan tingkat kerumitan atau kecanggihannya yang membuat ia digunakan dan menjadi pilihan sebagai acuan dalam melihat proses implementasi kebijakan. Justru karena kesederhanaannya yang menjadikannya menarik digunakan sebagai acuan.

\section{Metode Penelitian}

Metode yang digunakan oleh penulis dalam penelitian ini adalah metode penelitian kualitatif. Menurut creswell, (2010:4) penelitian kualitatif merupakan metode-metode untuk mengeksplorasi dan memahami makna yang oleh sejumlah individu atau kelompok orang dianggap berasal dari masalah social atau kemanusiaan. Metode kualitatif ini juga dapat dikatan berbasis informasi/kenyataan yang terjadi di lapangan. Proses penelitian ini melibatkan upaya-upaya penting seperti mengajukan pertanyaan-pertanyaan dan prosedurprosedur mengumpulkan data spesifik dari partisipan,menganalisis data secara induktif melaui tema-tema yang khusus ke tema-tema yang umum dan menafsirkan makna dari data.

Tujuan dari penelitian ini adalah mengetahui bagaimana implementasi kebijakan pajak reklame di Badan Pendapatan Daerah (BAPENDA) Kabupaten Subang. Pemilihan pendekatan kualitatif ditujukan untuk menjawab pertanyaan yang telah ditentukan melalui obeservasi dan wawancara.

\section{Hasil Penelitian Dan Pembahasan}

Badan Pendapatan Daerah (BAPENDA) Kabupaten Subang sebelumnya sudah mengalami beberapa kali pergantian nama. Dari Dinas Pendapatan, PEngelolaan Keuangan dan Aset Daerah (DPPKAD), lalu menjadi Badan Pengelola Keuangan dan Aset Daerah (BPKAD), sampai januari 2017 menjadi Badan Pengelolaan Keuangan Daerah (BPKAD). Hingga pada Januari 2018 menjadi Badan Pendapatan Daerah (BAPENDA) Kabupaten Subang. Hal tersebut dilakukan bukan tidak dengan atas dasar, namun sudah diatur dalam ketentuan Permendagri Nomor 5 tahun 2017 tebtang Pedoman Nomenklatur Perangkat Daerah Provinsi dan 
Kabupaten/Kota yang melaksanakan fungsi penunjang penyelengggaraan urusan pemerintahan. Tugas pokok dan fungsi antara Badan Pendapatan dan Badan Keuangan menurut sifatnya adalah berbeda. Badan Pendapatan titik beratnya adalah pemasukan Pendapatan ASli Daerah (PAD) sesuai dengan ketentuan perundang-undangan sedangkan Badan Keuangan lebih bertitik pada regulasi belanja serta penatausahaan keuangan dan barang milik daerah, sehingga pemisahan Badan tersebut diharpkan akan lebih tertib dalam pelaksanaan fungsi masing-masing Badan termaksud. Pemisahan Badan tersebut diharapkan dukungan SDM dan sarana prasarana akan lebih optimal dalam rangka optimalisasi tujuan. Visi dan misi organisasi baik dalam tugas-tugas badan pendapatan maupun badan keuangan. Adanya skoring Tupokasi dari BPKD mendapatkan nilai 1000 dan sudah memadai untuk dikembangkan menjadi dua Badan yang terpisah. Dengan dipisahkan BPKD menjadi dau badan maka diharapkan Badan Pendapatan akan focus dalam upaya realisasi PAD yang menjadi sumber pembiayaan penyelenggaraan pemerintahan. Sedangkan pada Badan Keuangan akan focus dalam upaya tertib pentatausahaan belanja dan peneglolaan keuangan dan asset daerah yang berimplikasi pada opini Badan Pemeriksa Keuangan (BPK) republic Indonesia. Adapun visi dan misi Badan Pendapatan Daerah (BAPENDA) Kabupaten Subang adalah "terwujudnya pengelolaan pendapatan daerah yang transparan, dinamis, dan akuntabel menuju struktur pendapatan dan yang kuat dan mandiri". Sedangkan Misi BAPENDA yaitu JAWARA (Jaya Istimewa Sejahtera) Negara; Jaya : terciptanya struktur pendapatan yang kuat dalam mendukung pembiayaan pembangunan; Istimewa : terwujudnya pelayanan prima yang transparan, dinamis, dan akuntabel; dan Sejahtera : terpenuhinya pembiayaan pembangunan yang mandiri. Badan Pendapatan Daerah adalah unsur penunjang Urusan Pemerintahan bidang pendapatan daerah yang menjadi kewenangan daerah Kabupaten Subang. Badan dipimpin oleh seorang Kepala Badan yang berada di bawah dan bertanggung jawab kepada Bupati melalui Sekretaris Daerah. Badan mempunyai tugas pokok membnatu Bupati dalam melaksanakan fungsi penunjang Urusan Pemerintahan di Bidang Pendaptan Daerah dan tugas pembantuan yang diberikan kepada Pemerintah Kabupaten. Kepala Badan mempunyai tugas pokok merencanakan, mengorganisir, melaksanakan, mengendalikan serta melaporkan kegiatan badan dalam melaksanakan sebagian Urusan Pemerintahan di bidang Pendapatan Daerah serta tugas pembantuan yang ditugaskan Bupati. Berdasarkan pasal 3 Pertauran Bupati Subang No. 71 Tahun 2018 BADAN mempunyai fungsi sebagai berikut: Perumusan kebijakan teknis di bidang Pendapatan Daerah; Penyelenggaraan urusan pemerintahan dan pelayanan umum di Pendapatan Daerah sesuai dengan ketentuan yang ditetapkan oleh Bupati; Pembinaan dan pelaksanaan kegiatan di bidang Pendapatan Daerah dan Pengelolaan administrasi umum, meliputi urusan perencaan, evaluasi dan pelaporan, urusan umum dan kepegawaian serta urusan keungan dan barang daerah.

\section{Impelementasi Kebijakan Pajak Reklame Di Badan Pedanpatan Daerah Kabupaten Subang}




\section{a. Dimensi Standar dan Sasaran Kebijakan}

Menurut Van Metter dan Van Horn dalam Subarsono (2005 : 99) standar dan sasaran kebijakan harus jelas dan terukur, apabila standar dan sasaran kebijakan kabur maka akan terjadi multi interpretasi dan menimbulkan konflik diantara para agen pelaksana. Standar dan sasaran kebijakan harus dapat dilihat secara spesifik sehingga di akhir kebijakan dapat diketahui keberhasilan atau kegagalan dari kebijakan yang dijalankan. Ketika satandar dan sasaran kebijakan terlalu ideal untuk dilaksanakan di tingkat masyarakat, maka akan sulit merealisasikan kebijakan public hingga titik yang dapat dikatakan berhasil. Berbicara masalah kebijakan pajak reklame, pemerintah Kabupaten Subang telah membuat kebijakan pengelolaan pajak reklame. Namun, dalam menjalankan kebijkanan tersebut jelas ada langkah-langkah yang harus dan wajib dilakukan oleh pemerintah. Dalam hal ini jelas pemerintah Kaupaten Subang yang memberikan mandatnya kepada BAPENDA sebagai Badan Pendapatan Daerah tidak lepas dari Peraturan Daerah Subang Nomor 10 Tahun 2010 tentang Pajak Reklame. Pemerintah perlu berupaya mengedepankan peran pasrtisipasi masyarakat dengan mengacu pada teori Bottom-Up pada implementasi keijakan pajak reklame. Hal ini dikarenakan kebijakan pajak reklame ini memang ditujukan kepada masyarakat yang menjadi wajib pajak dan dapat terpacu untuk bisa berpartisipasi dalam pelaksanaan penyelenggaraan reklame.

\section{a.1 Standar Kebijakan}

Standar kebijakan berbicara tentang suatu norma atau persyaratan yang biasanya berbentuk suatu dokumen formal yang menciptakan kriteris, metode, dan proses. Standar kebijakan membantu untuk memastikan keamanan kebijakan dan biasanya mengandung control keamanan yang berkaitan dengan implementasi kebijakan juga. Standar dalam suatu kebijakan sangat diperlukan adanya, agar kebijakan tersebut ketika dilaksanakan atau diimplementasikan tidak akan kabur dari tujuan kebijakan yang telah ditentukan. Kejelasan standar juga sangat diperlukan agar tidak terjadi multitafsir bagi penerima kebijakan. BAPENDA telah membuat standar bagi pelaksanaan reklame di Kabupaten Subang. Seperti yang dituturkan oleh Kepala Sub Bidang pelayanan dan penetapan pajak reklame di BAPENDA sebagai berikut : “standar kebijakan pajak reklame beorientasi kepada Undang-undang Nomor 28 Tahun 2009 tentang pajak daerah dan retribusi daerah. Mengingat bahwa sekarang itu pemerintahan sudah bersifat desentralisasi yaitu daerah bisa mengurus rumah tangga daerahnya sendiri, Kabupaten Subang membuat peraturan daerah sendiri tentang pajak daerah dan salah satunya kebijakan pajak reklame. Kebijakan tersebut tertuang pada Peraturan Daerah Kabupaten Subang Nomor 10 Tahun 2010 tentang pajak daerah. Di dalamnya termuat tata cara atau prosedur pelaksanaan rekalme, yaitu mengenai penetapan pajak reklame sesuai jenis reklame, pembayaran pajaknya, syarat berdirinya reklame itu, dan yang terakhir urus izinnya. Jadi standar pelaksanaan kebijakan pajak reklame adalah Perda Kabupaten Subang Nomor 10 Tahun 2010 dan merupakan standar untuk melaksanakan reklame di Subang". Berdasarkan 
dari hasil wawancara tersebut tergambarkan bahwa yang menjadi standar kebijakan pajak rekalme di Kabupaten Subang adalah Perda Subang Nomor 10 Tahun 2010 tentan Pajak daerah. Dari kebijakan tersebut yang kemudian lahirnya Standar Operasional Prosedur bagi wajib pajak yang akan menerbitkan reklame. Dimulai dari membuat pengajuan penerbitan reklame dan pembayaran pajak reklame sesuai jenis reklame karena tarif pajaknya tergantung berdasarkan jenis reklame, apakah reklame permanen atau non permanen. Reklame yang sudah selesai mengurus pengajuan terbit dan membayar pajak dapat diterbitkan. Setelah itu wajib pajak harus pula mengurus izin penayangan reklame, walaupun untuk perizinan itu sendiri tidak menjadi hal utama. Namun pada kenyataannya banyak wajib pajak reklame yang tidak mengurus izinnya, karena yang mereka tahu untuk penerbitan suatu reklame itu harus membayar pajak terlebih dahulu. Berbeda dengan peraturan sebelumnya yang mengharuskan mengurus perizinan sebelum membayar pajak, peraturan yang baru lebih menekankan kepada pembayaran pajaknya terlebih dahulu kemudian reklame dapat diterbitkan. Maka banyak wajib pajak yang mengabaikan untuk mengurus perizinan penayangan reklame. Hal ini menandakan kurangnya sosialisasi dari pihak BAPENDA terhadap wajib pajak mengenai standar kebijakan reklame.

\section{a.2 Sasaran Kebijakan}

Sasaran merupakan penjabaran dari tujuan yaitu sesuatu yang ingin dicapai atau dihasilkan suatu instansi pemerintah dalam jangka waktu tahunan, semesteran, triwulan, atau bulanan. Kebijakan pajak reklame menentukan sasaran pajak per periodenya selama satu tahun sekali. Sasarannya berupa target yang ingin dicapai tahun ini, dan tentu akan meningkat dari tahun sebelumnya. Sasaran BAPENDA sendiri yaitu meningkatkan Pendapatan Daerah Kabupaten Subang di bidang perpajakan. Mulai dari pajak PBB dan Pajak Daerah Lainnya termasuk reklame. Tujuannya untuk membantu pembangunan daerah dari segi anggaran. Seperti terciptanya sarana-sarana yang akan dinikmati oleh seluruh masyrakat dan dirasakan pula manfaatnya. Target sasaran dalam pembayaran pajak reklame ini adalah Peningkatan Pendapatan Asli Daerah melalui pajak yang disetorkan wajib pajak reklame. Hal tersebut seperti yang dituturkan oleh kepala Sub Bidang Penetapan dan Pelayanan Pajak Daerah Lainnya sebagai berikut : “Sasaran Perda Nomor 10 Tahun 2010 tentang pajak reklame ini adalah untuk membantu pembangunan daerah dalam segi peningkatan Pendapatan Asli Daerah. Sesuai tugas pokok dan fungsi BAPENDA yaitu melakukan pemungutan pajak terhadap wajib pajak reklame. Kemudian hasil penagihan pajak reklame itu akan kami setorkan sebagai Pendapatan Asli Daerah. Tentunya dengan upaya-upaya target pencapaian kami tiap tahun yang terus meningkat. Namun tidak dengan disertai realisasinya. Pajak Reklame kerap mengalami penurunan pencapaian target seperti pada tahun 2018 mengalami penurunan dari tahun sebelumnya. Terlepas dari semua itu kami selalu mengupayakan agar tidak terjadi penurunan". Dari pernyataan tersebut dapat dilihat bahwa 
pencapaian pajak di bidang reklame selalu meningkat dan bahkan dapat dibilang terbaik. Namun pada tahun 2018 mengalami penurunan pencapaian. Hal itu tentu mempengaruhi PAD Kabupaten Subang. Berdasarkan hasil penelitian pada bidang pajak daerah lainnya, pajak reklame merupakan pajak daerah lainnya yang sangat berkontribusi bagi PAD Subang. Bidang reklame menempati urutan pertama dan terbanyak pada bidang pendapatan daerah lainnya. Kemudian disusul oleh hotel, restaurant, tempat hiburan, dan lainnnya. Dapat dilihat dari ujung utara hingga selatan banyaknya reklame di Kabupaten Subang. BAPENDA selalu mengupayakan agar peningkatan di bidang pajak reklame meningkat walau dalam realisasinya ada saja mengalami penurunan dalam kurun waktu tertentu. Jika dilihat dari kinerja implementor sudah cukup baik. Tetapi tetap saja ada satu dan lainnya faKtor yang menyebabkan pajak reklame mengalami penurunan pencapian.

\section{b. Dimensi Sumber Daya}

Saat menjelaskan mengenai sumber daya yang dimaksud Van Metter dan Van Horn adalah hal-hal yang meliputi sumber daya manusia maupun sumber daya yang bukan manusia yang digunakan dalam pelaksanaan kebiajakan. Menurut Van metter dan Van Horn sumber daya memiliki posisi sangat penting dalam keberhasilan implementasi kebijakan. Tanpa kecukupan sumber daya, apa yang direncanakan tidak akan sama dengan apa yang akhirnya di terapkan. Sumber daya menjadi salah satu yang perlu mendapat perhatian dari suatu proses implementasi kebijakan. Hal ini bertujuan agar saat suatu kebijakan dilaksanakan terlaksana secara efektif dan efisien. Tanpa adanya sumber daya, kebijakan hanya tinggal diatas kertas saja dan hanya akan menjadi dokumen tertulis saja, karena sumber daya merupakan penentu apakah suatu kebijakan dilaksanakan atau tidak. Sumber daya yang menjadi paling penting disini adalah sumber daya manusia karena manusia merupakan pemikir, pelaksana dan pengawas terhadapa suatu kebijkan. sumber daya juga meliputi dana atau biaya, serta keahlian-keahlian yang baik untuk melaksanakan tugas-tugas mereka, informasi, wewenang, dan fasilitas-fasilitas yang diperlukan untuk menterjemahkan kebijakan guna melaksanakan kebijakan tersebut. Begitu pula dalam Implementasi Kebijakan Pajak Reklame ini memerlukan sumber daya yang berkualitas.

\section{b.1 Staff}

Pembahasan pada staff diarahkan pada pembahasan kualitas pegawaipegawai yang akan terlibat dalam pembuatan maupun pelaksanaan kebijakan. Menurut Van Metter dan Van Horn pembahasan mengenai staff tidak hanya membicarakan besaran saja. Karena keberhasilan implementasi juga sangat dipengaruhi oleh kemampuan staff pelaksana. Ada dua besaran pokok pada sumber daya yang dibuthkan untuk impelemntasi kebijakan public, yaitu size dan skill. Pelaksana kebijakan Pajak Reklame di Bapenda Kabupaten Subang masih kurang di sisi sumber daya. Seperti yang diungkapkan oleh Kepala seksi penetapan dan pelayanan Pajak Reklame 
Bapenda Subang bahwa terdapat kekurangan sumber daya manusia dalam melaksanakan kebijakan Pajak Reklame ini. Pernyataan Tersebut disampaikan sebagai berikut:" pegawai atau tim pelaksana Pajak Reklame di Bapenda ini masih sangat kurang. Saat ini untuk bagian administrasi di kantor atau pelayanan hanya ada 1 orang, dan 2 orang untuk di lapangan. Sedangkan pajak Rekleme itu tidak seperti pajak hotel atau pajak restoran atau pajak daerah lainnya yang tidak terlalu membutuhkan banyak pegawai.

\section{b.2 Infomasi}

Dua hal yang penting dibahas berkaitan dengan informasi sebagai factor berpengaruh kedua terhadap sumber daya adalah informasi yang berkaitan dengan bagaimana kebijakan harus diketahui berkenaan dengan pelaksanaan kebijakan. Agar implementasi dapat mencapai tujuan-tujuan yang diharapkan, maka informasi yang baik berhubungan dengan cara mengimplementasikan kebijakan berupa atura-aturan hukum harus jelas. Informasi berdasarkan aturan tersebut yaitu Peraturan Bupati Subang Nomor 38 Tahun 2010 tentang, "Petunjuk Pelaksanaan Peraturan Daerah Pajak Daerah Nomor 10 Tahun 2010 Pajak Reklame".

\section{b.3 Wewenang}

Wewenang sangat diperlukan, terutama untuk menjamin dan meyakinkan bahwa kebijakan yang akan dilaksanakan adalah sesuai dengan yang mereka kehendaki. Searah dengan hal tersebut, dalam implementasi Kebijakan Pajak Reklame memiliki struktur pelaksana bertingkat. Kebijakan tidak akan dapat diterapkan apaila tidak disertai pendelegasian wewenang kepada implementor.

\section{b.4 Fasilitas}

Sumber daya lain yang juga tidak kalah penting adalah adanya fasilitas pendukung yang dapat dipakai untuk melekukan kegiatan program seperti sara dan prasarana. Hal terpenting didalamnya adalah sumber daya keuangan finansial untuk memnunjang implementasi kebijakan. Apabila kebijakan yang dibuat adlaah kebijakan pulik, sudah tentu dukungan keuangan berasal dari pemerintah. Semakin tinggi dukungan dari pemerintah, semakin baik implementasi kebijakan. Demikian pula sebaliknya, semakin kecil dukunagn finansial dari pemerintah bagi suatu kebijaknan, akan dapat menjadi penyebab dari terhambtanya bahkan gagalnya implementasi suatu kebijakan.

\section{c. Dimensi Hubungan Antar Organisasi}

Suatu kebijakan tidak akan berpengerauh hanya pada satu pihak saja, tetapi akan berkaitan bahkan saling ketergantungan kepada pihak lain yang terlibat di dalamnya. Maka dari itu, hubungan antar organisasi selalu ada dalam setiap implementasi suatu kebijakan. Hubungan yang dijalin yaitu kerjasama dalam bentuk komunikasi baik satu arah maupun dua arah. Disini akan dilihat apakah 
dari sisi hubungan antar organisasi lain implementasi kebijakan pajak reklame sudah efektif. Mengingat betapa pentingnya pajak reklame bagi pendapatan daerah Kabupaten Subang, maka dalam kebijakan yang mengaturnya pun sangan terperinci. Pajak Reklame Diatur mulai dari pemohonan terbit reklame, pembayaran pajak, perizinan reklame, hingga penertiban reklame yang sudah habis masa tayangnya. maka dari itu implementasi Kebijakan Pajak Reklame yang dibuat pemerintah ini tidak akan berjalan dengan baik jika tidak ada dukungan dari pihak-pihak terkait yang mendukung kebijakan Pajak Reklame ini. Dalam penelitian ini ditemukan kerjasama yang terjalin antara beberapa pihak terlibat dalam impelemntasi kebijakan pajak reklame, alur hubungan terjadi tiga arus. Hubungan yang pertama terjadi antara pembuat kebijakan dengan pelaksana kebijakan dan penerima kebijakan. Serta pada saat yang bersamaan terjadi hubungan dalam bentuk langsung antara pembuat kebijakan dengan penerima kebijakan. Hubungan yang terjadi dalam implementasi kebijakan pajak reklame ini yaitu antara pihak Bapenda dengan wajib pajak. Dengan adanya kebijakan Pajak Reklame ini Bapenda diberi kewenangan untuk mengelola sendiri penggunaan dananya dalam hal proses pembangunan daerah namun tetap dengan peraturan yang ada.

Koordinasi bisa dikatakan suatu kerja sama yang dilakukan oleh berbagai pihak dalam melakukan kegiatan yang berbeda-beda agar berjalan optimal sesuai dengan apa yang menjadi tujuan awal. Mengingat kompleksitas daripada organisasi maka sudah jelas diperlukan adanya peran daripada koordinasi. Tanpa adanya koordinasi yang baik, maka dimungkinkan masing-masing orang tersebut akan bekerja sendiri-sendiri yang tentunya tidak menutup kemungkinan mengakibatkan suatu hambatan terhadap usaha-usaha pencapaian tujuan organisasi. Badan Pendapatan Daerah melakukan koordinasi dengan Dinas Penanaman Modal dan Pelayanan Terpadu Satu Pintu (DPMPTSP) untuk masalah perizinan reklame yang akan diterbitkan. Hubungan yang terjadi berupa komunikasi atau penerusan peraturan prosedur penerbitan reklame tidak terlalu intens dan sering dilakukan oleh Bapenda. Hal ini disampaikan oeleh informan Kepala seksi perizinan DPMPTSP Kabupaten Subang : "Hubungannya tidak terlalu intens. Hanya melakukan kunjungan untuk pengecekkan jumlah reklame yang memiliki atau yang mengurus izinnya. Hal ini dikarenakan berbeda dengan peraturan daerah Kabupaten Subang yang dulu, dalam peraturan daerah Kabupaten Subang yang baru di dalamnya di sebutkan bahwa wajib pajak reklame terlebih dahulu harus membayar pajak dan kemudian mengurus izinnya. Jadi permohonan penerbitan reklame itu disampaikan kepada Bapenda bukan DPMPTSP. Setelah wajib pajak mengurus pajaknya maka dapat terbitlah reklame tersebut. Banyak yang mengurus izin setelah reklamenya tayang. Tapi kebanyakan yang meminta izin kepada DPMPTSP adalah wajib pajak yang reklamenya terpasang untuk waktu yang cukup lama atau permanen. Seperti rokok dan took-toko". Berkenaan dengan hal itu menandakan bahwa Bapenda berperan penuh dalam kebijakan pajak rekalme di Kabupaten Subang. Namun terlepas dari itu, Bapenda juga seharusnya mensosialisasikan bahwa membayar pajak memang yang utama, namun setelahnya diperlukan mengurus izinnya baik untuk reklame yang bersifat sementara maupun permanen. Terkait dengan bentuk sosialisais kebijakan pajak reklame yang disampaikan oleh 
BAPENDA kepada tiap-tiap wajib pajak yang mengajukan permohonan penayangan rekalme, menurut keterangan wajib pajak disampaikan bahwa BAPENDA belum melakukan sosialisasi mengenai pengurusan izin reklame. Hal itu seperti pernyataan wajib pajak reklame yang memiliki reklame tayang sementra atau non permanen sebagai berikut : "Peraturan sebelumnya mengharuskan wajib pajak mengurus izinnya terlebih dahulu lalu setelah terbit diwajibkan membayar pajak. tetapi setelah peraturan baru ada, yang penting wajib pajak membayar pajak reklame sudah dapat ditayangkan. Oleh karena itu wajib pajak tidak mengurus izinnya apalagi untuk reklame event sperti ini".

\section{d. Komunikasi}

Jika Implementasi Kebijakan Pajak Reklame ingin berlangsung secara efektif, maka perintah-perintah pelaksanaan harus konsisten dan jelas. Komunikasi internal antara BAPENDA dengan pihak terkait tidak berjalan dengan baik karena peaksanaan perintah yang tidak jelas dalam pelaksanaan peraturan daerah tentang pajak reklame ini. Dalam hal ini BAPENDA melakukan komunikasi secara acak dan tidak berkala kepada pihak terkait yang juga berkepentingan bagi berlangsungnya kebijakan pajak reklame. Hal ini seperti yang dituturkan oleh kepala seksi penetapan dan pelayanan pajak reklame :"sejauh ini BAPENDA tidak pernah melakukan komunikasi lain seperti rapat ataupun kunjungan kerja terhadap pihak terkait mengenai pajak reklame. Yang dilakukan hanya pengecekkan data dan penerusan peraturan yang ada". Hal ini menggambarkan bahwa memang tidak ada komunikasi yang secara jelas dan terukur untuk dilakukan BAPENDA terhadap pihak-pihak terkait. Maka dari itu dalam melaksanakan tugas pun terkesan masingmasing antara beberpa pihak terkait yang ada.

Berdasarkan keterangan di atas dapat disimpulkan bahwa terciptanya hubungan antara pembuat kebijakan dengan pelaksana kebijakan serta penerima kebijakan dalam Implementasi Kebijakan Pajak Reklame sangat penting. Dilihat dari indicator koordinasi belum terlaksana secara efektif, terdapat pesan yang sulit dijabarkan oleh pihak-pihak yang terlibat. Serta pada indicator komunikasi, tidak adanya penetapan komunikasi yang jelas, terukur dan berkala itu juga tidak akan berdampak baik terhadap hubungan antar organisasi.

\section{e. Karakteristik Agen Pelaksana}

Tujuan implementasi kebijakan diformulasikan ke dalam suatu aturan tertentu yang dirancang dan dibiayai oleh pemerintah. Implementasi kebijakan secara garis besar dipengaruhi oleh isi kebijakan dan konteks Implementasi. Keseluruhan implementasi kebijakan lalu di evaluasi dengan cara mengukur keluaran (output) yang dihasilkan berdasarkan tujuan kebijakan. Keluaran (output) kebijakan dilihat melalui dampaknya terhadap sasaran yang dituju baik individu maupun kelompok masyarakat. Karakteristik agen pelaksana mencakup struktur birokrasi, normanorma dan pola-pola hubungan yang terjadi dalam birokrasi yang semuanya itu akan mempengaruhi implementasi. Dalam melaksanakan Kebijakan Pajak Reklame agar tercapai dengan baik maka harus disusun dalam urutan-urutan yang tepat seluruh tugas yang kemudian disebut Standar Operasional Prosedur (SOP) dan dilakukan oleh setiap pihak yang terlibat dalam pelaksanaan implementasi kebijakan Pajak Reklame di BAPENDA Kab. Subang. Pada akhirnya komitmen 
aparat pelaksana untuk merealisasikan tujuan yang telah tertuang dalam kebijakan adalah hal yang paling penting. Aparat Badan Pelaksana harus memiliki keterampilan dalam membuat prioritas tujuan dan selanjutnya merealisasikan prioritas tujuan tersebut.

Hal tersebut seperti yang diutarakan oleh Kepala Sub Bidang Penetapan dan Pelayanan Pajak Daerah LAinnya sebagai berikut :“Tentu saja sebagai pelaksana harus menjalankan Kebijakan ini sesuai dengan norma-norma yang ada atau biasanya disebut Standar Operasional Prosedur yang tertuang dalam PerBup Subang No. 38 Tahun 2010. Kami juga komitmen dalam melakukan pelaksaanaan kebijakan ini". Berdasarkan hasil pemaparan tersebut sudah jelas bahwa pelaksana melakuakn tugas yang diberikan seuai dengan norma-norma dan aturan-aturan yang telah ditetapkan dalam Peraturan Bupati Subang Nomor 38 Tahun 2010 tentang Petunjuk Pelaksanaan Peraturan Daerah Pajak Daerah Nomor 10 Tahun 2010 Pajak Rekalme. Selain itu petugas atau pelaksana juga komitmen dalam melaksanakan tugas. Komitmen yang dimaksud disini yaitu tidak membeda bedakan tugas atau pelayanan yang diberikan baik kepada wajib pajak yang berasal dari perusahaan besar ataupun perusahaan dan wirausaha kecil.

Berdasarkan pemaparan di atas dapat disimpulkan bahwa karakteristik agen pelaksana kebijakan pajak reklame sudah berjalan optimal. Hal ini terlihat dari penuturan yang sama antara pelaksana kebijakan yaitu pihak BAPENDA dan penerima kebijakan yaitu pihak Wajib Pajak Reklame. Aparat pelaksana atau petugas melakukan tugas sesuai dengan aturan yang telah diberikan dan komitmen dalam menjalankan tugas sudah baik dengan cara tidakk membeda-bedakan wajib pajak reklame yang ada. Sehingga dimensi ini sudah berjalan optimal karena memiliki sisi positif baik dari aparat sebagai pelaksana kebijakan maupun wajib pajak sebagai penerima kebijakan.

\section{f. Kondisi Sosial, Politik dan Ekonomi}

Pajak reklame adalah salah satu pendapatan daerah Kabupaten Subang. Pendapatan daerah menjadi sangat penting karena berdampak pada kemajuan pembangunan daerah yang kemudian berperan sebagai sebagai modal setiap daerah melaksanakan rumah tangganya masing-masing. Pembangunan yang dimaksud meliputi infrastruktur maupun pembangunan birokrasi pemerintah itu sendiri. Maka dari itu, ketika salah satu saja dari sumber pendapatan daerah mengalami penurunan target, akan berdampak pada daerah tersebut. Salah satu upaya yang dibuat oleh Pemerintah Daerah Subang adalah dengan membuat Perda Nomor 10 Tahun 2010 Tentang Pajak Reklame. Dalam program ini banyak pihak mulai dari pelaksana kebijakan hingga penerima kebijakan disadarkan bahwa ketika ingin derah tersebut maju makka harus dengan bijak dan benar adanya dalam pengelolaan pendapatan daerah salah satunya pajak reklame.

Dari pernyataan di atas terlihat bahwa kondisi social, politik dan ekonomi yang menjadi sasaran wajib pajak berbeda-beda pada setiap daerahnya. Pada daerah yang kondisi social dan ekonomi yang rendah pun dapat menjadi potensi reklame karena yang memasang reklame belum tentu yang memiliki daerah tersebut. Kemudianyang menjadi salah satu factor yang mendukung keberhasilan kebijakan ini adalah lingkungan yang memiliki banyak potensi reklame. Jadi mau bagaimanpun kondisi social, politik dan ekonomi suatu daerah itu tidak terlalu 
berpengaruh terhadap kebijakan reklame. Hal tersebut dibenarkan oleh wajib pajak reklame yang terhutang sebagai berikut :"Di daerah kami dan daerah lainnya tentu memiliki kondisi social, politik dan ekonomi yang berbeda-beda. Ketika saya memasang reklame tentunya memilih daerah yang dapat diperkirakan akan banyak orang yang akan melihat reklame saya. Dengan begitu unsur komersial dari kami tersampaikan dan itu menjadi keuntungan bagi kami karena dapat meningkatkan penghasilan bagi kami".

Berdasarkan dari hasil pemapran diatas dapat disimpulkan bahwa dimensi kondisi social, ekonomi dan politik sudah berjalan optimal. Dilihat dari sejauh mana kondisi lingkungan yang dapat menjadi potensi bagi reklame dan kepentingan kelompok yang tidak merugikan bagi pelaksana kebijkan maupun penerima kebijakan.

\section{g. Disposisi Implementor}

Pelaksana kebijakan memiliki nilai-nilai aturan yang bisa jadi berbeda antara satu dengan yang lain. Perbedaan nilai ini menimbulkan perbedaan kebijakan atau penilaian terhadap kebijakan yang ada. Jika perbedaan nilai antara pembuat kebijakan dengan pelaksana kebijakna cukup besar dan cenderung berlawanan arah, maka pelaksanaan kebijakan akan berada pada tahap yang sulit. Keengganan bahkan pergeseran yang menimbulkan perdebatan maupun perpecahan, akan muncul menghambat pelaksana kebijakan. Keberhasilan implementasi juga dipengaruhi oleh bagaimana karakteristik implementor dan orang yang menerima kebijkan dengan berbagai permasalahan yang dihadapinya. Karakteristik tersebut yang kemudian disebut dengan Disposisi Implementor Menurut Van Metter dan Van Horn. Apabila implementor memiliki disposisi yang baik, maka dia akan menjalankan kebijakan dengan baik seperti apa yang dihiarapkan oleh pembuat kebijakan. Namun sebaliknya, ketika iplementor tidak bisa bersikap seperti apa yang dihiarapkan oleh pembuat kebijakan, maka proses implementasi kebijakan tidak akan berjalan secara optimal. Berbagai pengalaman pembangunan di negara yang masih berkembang menunjukkan bahwa tingkat komitmen dan kejujuran aparatur masih sangat rendah. Berbagai kasus korupsi yang muncul di salah satu negara berkembang seperti Indonesia adalah contoh konkret dari rendahnya komitmen dan kejujuran aparatur dalam mengimplementasikan kebijakan demi mendukung pembangunan suatu negara ataupun daerah.

Berdasarkan beberapa keterangan hasil penelitian dapat dikemukakan bahwa disposisi dalam implementasi kebijakan Pajak Reklame di pihak pelaksana kebijakan yaitu BAPENDA dan penerima kebijakan yaitu wajib pajak menunjukkan sikap positif dan mendukung terhadap terlaksananya Kebijakan Pajak Reklame. Implementasi Kebijakan yang dilaksanakan dengan memberdayakan Badan Pendapatan Daerah (BAPENDA) sebagai perpanjangan tangan antara pemerintah dengan masyarakat yang menjadi wajib pajak dan memberikan informasi ataupun penjelasan. Jadi berdasarkan pembahasan di atas dapat diketahui bahwa implementasi kebijakan merupakan pelaksanaan kebijakan dasar, biasanya dalam bentuk undang-undang, namun dapat pula berbentuk peraturan-peraturan yang penting atau keputusan badan peradilan. Keputusan tersebut dibuat untuk mengatasi permasalahan yang terjadi, sehingga apabila telah melalui suatu proses akan dihasilkan suatu output kebijakan dan akan diketahui dampaknya bagi 
kelompok sasaran. Hal itu terlihat dalam kebijakan Pajak Reklame di BAPENDA Kabupaten Subang, dari Kepala Sub Bagian Penetapan dan Pelayanan, wajib pajak, dan juga instansi-instansi atau pihak-pihak terkait yang berusaha menjalankan kebijakan Pajak Reklame ini tepat sasaran.

\section{Kesimpulan}

Berdasarkan hasil analisis dan pembahasan yang dilakukan, dapat ditarik kesimpulan mengenai Implementasi Kebijakan Pajak Reklame Di Badan Pendapatan Daerah Kabupaten Subang sebagai berikut:

1) Standar dan Sasaran Kebijakan ; Pelaksanaan kebijakan Pajak Reklame adalah suatu kebijakan yang dibuat pemerintah daerah untuk mengupayakan peningkatan Pendapatan Asli Daerah (PAD). Standar dan Sasaran Kebijakan ini masih terasa kabur karena terjadi multi interpretasi dan multi tafsir mengenai standar kebijakan antara pelaksana kebijakan dengan penerima kebijakan, yaitu petugas pajak reklame BAPENDA dan wajib pajak reklame. Pada sasaran sudah tepat sasaran yaitu kebijakan ini ditujukan kepada wajib pajak yang memiliki reklame. Namun, pada sasaran lainnya yaitu untuk peningkatan PAD belum optimal karena terjadi penurunan target pencapaian dari tahun 2017 ke tahun 2018.

2) Sumber Daya; Pelaksanaan kebijakan Pajak Reklame di BAPENDA KAbupaten Subang lemah dari sisi sumber daya. Pada indikator staf, belum terlaksana secara optimal dilihat dari sedikitnya staf yang dimiliki dan dengan keterampilan yang terbatas pula. Kemudian indikator informasi, dalam hal ini sudah terlaksana sesuai dengan ketentuan pada buku Petunjuk Teknis Pemungutan Pajak Reklame. Selanjutnya indikator wewenang, terlihat bahwa pelaksana kebijakan bergerak sesuai dengan SK (Surat Keputusan) dan indikator terakhir yakni fasilitas, mengenai hal ini sarana prasarana pendukung kebijakan pajak reklame kurang memadai terutama anggaran yang digelontorkan pemerintah sangat terbatas. Baik untuk pelaksanaan kebijakan maupun insentif petugas pajak.

3) Hubungan antar organisasi; Dalam proses Implementasi Kebijakan Pajak Reklame di BAPENDA Kabupaten Subang, baik komunikasi antara Lembaga pemerintah maupun, antar organisasi terkait, maupun dengan penerima kebijakan hubungannya belum optimal dan tidak terjalin seperti seharusnya.

4) Karakteristik Agen Pelaksana; Aparatur pelaksana yang bertugas sebagai agen pelaksana di tingkat Kabupaten dalam hal ini mengenai kebijakan Pajak Reklame sudah cukup baik, komitmen dan konsistensi implementor dari pimpinan sampai pelaksana untuk mengimplementasikan kebijakan sesuai dengan tujuan kebijakan yang telah ditentukan.

5) Kondisi Sosial, Ekonomi dan Politik; Dimensi ini dapat dikatakan optimal. Kondisi social, politik dan ekonomi memang selalu berbeda-beda, akan tetapi hal tersebut tidak tidak menjadi hambatan. Hal itu disebabkan bahwa yang menjadi konsentrasi kebijakan ini adalah suatu lingkungan atau daerah yang menjadi potensi reklame.

6) Disposisi Implementor; Dikalangan instansi pemerintah dan wajib pajak menunjukkan sikap positif dan mendukung terhadap terlaksananya Kebijakan 
Pajak Reklame. Implementasi kebijakan yang dilaksanakan dengan memberdayakan BAPENDA sebagai perpanjangan tangan antara pemerintah dengan wajib pajak dan memberikan informasi ataupun penjelasan.

Sesuai dari kesimpulan keenam dimensi menurut Van Metter dan Horn dalam Subarsono, (2005:99) diatas dapat dilihat bahwa inplementasi Kebijakan Pajak Reklame di BAPENDA Kabupaten Subang masih mnegalami masalah dari dimensi standar dan sasaran kebijkan karena masih terjadi penurunan pendapatam. dimensi sumber daya dimana jumlah pegawai yang masih kurang dan sarana prasarana yang belum mencukupi plekasanaan kebijakan. Yang terakhir Hubungan Antar Organisasi yang masih terkesan masing-masing dan tidak adanya komunikasi secara jelas dan terukur yang terjalin antar Lembaga terkait.

\section{Referensi}

Abdul Wahab, Solichin. 2004. Analisis Kebijaksanaan, Dari Formulasi Ke Implementasi Kebijakan Negara. Jakarta: Bumi Aksara.

Agustino, Leo. 2016. Dasar-Dasar Kebijakan Publik. Bandung : Alfabeta .

Bagong, Suyanto. 2005. Metode Penelitian Sosial: Berbagai Alternatif Pendekatan. Jakarta: Prenada Media.

Dunn, William N. 2003. Pengantar Analisis Kebijakan Publik. Terjemahan Samodra Wibawa. Edisi Kedua. Cetakan Kelima. Yogyakarta: Gajah Mada University Press.

Idrus, Muhammad. 2009. Metode Penelitian Sosial Pendekatan Kualitatif dan Kuantitatif. Edisi Kedua. Jakarta: Erlangga.

Mardiasmo, 2016. Perpajakan. Yogyakarta : ANDI.

Peraturan Daerah Kabupaten Subang Nomor 10 Tahun 2010 tentang Pajak Daerah.

Peraturan Pemerintah Nomor 55 Tahun 2016 tentang Ketentuan Umum dan Tata Cara Pemungutan Pajak Daerah.

Peraturan Bupati Nomor 38 Tahun 2010 tentang Petunjuk Pelaksana Peraturan Daerah Pajak Daerah No. 10 Tahun 2010 Pajak Reklame.

Rusli, Budiman. 2013. Kebijakan Publik. Bandung: Hakim Publishing.

Sugiyono. 2007. Metode Penelitian Administrasi. Bandung: CV Alfabeta.

Tachjan. 2006. Implementasi Kebijakan Publik. Bandung: AIPI dan Puslit KP2W Lembaga Penelitian Unpad.

Thoha, Miftah, 2010. Ilmu Administrasi Publik Kontemporer. Jakarta: Kencana.

Undang-Undang Nomor 28 Tahun 2009 tentang Pajak Daerah dan Retribusi Daerah. 


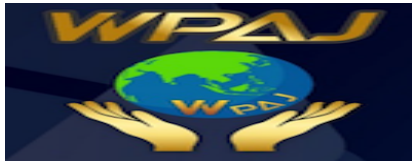

Volume 1 Issue 1, Juni 2019

https:/ / ejournal.unsub.ac.id/index.php/publik

W. Creswell, Jhon. 2010. Research design Pendekatan Kualitatif, Kuantitatif, dan Mixed. Yogyakarta: Pustaka Pelajar.

Winarno, Budi. 2007. Kebijakan Publik-Teori E Proses. Jakarta: PT BUKU KITA 